\title{
Ultrastructural Characterization of the Pars Distalis of the Indian Female Sheath-Tailed Bat, Taphozous longimanus (Hardwicke)
}

\author{
Caracterización Ultraestructural de la Pars Distalis del Murciélago \\ Cola de Vaina Hembra Indio, Taphozous longimanus (Hardwicke)
}

Archana A. Nerkar \& Mohan M. Gadegone

NERKAR, A. A. \& GADEGONE, M. M. Ultrastructural characterization of the pars distalis of the Indian female sheath-tailed bat, Taphozous longimanus (Hardwicke). Int. J. Morphol., 28(3):787-801, 2010.

SUMMARY: The present ultrastructural observations demonstrate the presence of six cell types in the pars distalis of nonpregnant and pregnant bats of Taphozous longimanus. In the pars distalis of T. longimanus, STH cells are round to oval with eccentrically placed nucleus, numerous secretory granules and well developed Golgi indicate a cell under vigorous synthetic activity while those filled with secretory granules with reduced Golgi complex suggest reserve or storage state of cells. LTH cell is characterized by the large secretory granules, dilated endoplasmic reticulum and numerous mitochondria in the cytoplasm which indicate that these cells are hypertrophied and synthetically very active during pregnancy. ACTH cells are found either singly or in groups and are elongated or angular with long cytoplasmic processes. The size and peripheral arrangement of secretory granules are characteristic of ACTH cell. TSH cells are distributed mostly towards the periphery of the pars distalis of T. longimanus. They are elongated, polygonal or triangular in shape. The secretory granules are small, electron dense, 150-200 $\mathrm{nm}$ in diameter. The rough endoplasmic reticulum is very well developed. In FSH, the secretory granules are small $(200$ to $400 \mathrm{~nm})$ and less in number and are distributed towards the periphery of the cell. FSH cells show well developed mitochondria, Golgi and rough endoplasmic reticulum indicating active state of FSH during estrus and pregnancy. The hypertrophy of FSH and LH cells during pregnancy is associated with filigreed cytoplasmic pattern giving a bizarre appearance. At late pregnancy, FSH and LH cells are highly active and synthesize large quantities of hormone as indicated by the development of cell organelles.

KEY WORDS: Bat; Pars distalis; Ultrastructure; Pregnancy.

\section{INTRODUCTION}

One of the most compelling questions addressed by bat Physiologist today is how neuroendocrine mechanism supports the diverse array of reproductive patterns that have evolved within the Chiropteran order. The ultrastructural study of the pars distalis has been mainly investigated in laboratory mammals, with the goal of defining not only microscopic characteristics but also the physiological significance of different cell categories with respect to reproduction. The influence of pituitary hormones, such as, $\mathrm{LH}, \mathrm{FSH}$ and prolactin are fundamental to reproductive physiology. These cells of pars distalis not only play a pivotal role in reproductive processes of mammals but also show changing morphology during different phases of reproductive cycle of bats (Herlant, 1962; Peyre \& Herlant, 1963; Badwaik, 1988, 1991; Richardson, 1979; O'Brien et. al., 1996; O’Brien, 2003).

Cell Biology Section, Department of Zoology, Institute of Science, India.
Morphological studies at electron-microscopic level continue to extend our knowledge of the pituitary's functional organization. Azzali (1971) studied the cytology and physiology of the adenohypophysis of Vesperugo savi and Vesperugo piccolo and identified six types of secretory cells and a seventh type without secretory granules. Bhiwgade, et al. (1989) studied the ultrastructural and functional characteristics of the anterior pituitary cells in the Indian fruit bat, Rousettus leschenaulti. Ultrastructural changes in gonadotropic and prolactin cells of Myotis myotis under experimental conditions have been studied by Muniz et al. (1991). In Vespertilionid bat, Scotophilus heathi electron microscopic studies revealed six distinct cell types in the pars distalis on basis of specific morphological characters, staining reactions and immunocharacteristics (Singh \& Krishna, 1994; 1997). 
Although Chiropterans are the second largest order of mammals, detailed reproductive patterns and their associated endocrine characteristic have been documented in only a few species. The detailed reproductive patterns have been described in the emballonurid bat, T. longimanus from India (Gopalakrishna, 1955, Krishna \& Dominic, 1982). T. longimanus shows geographic variation in the reproductive patterns. In Varanasi, India, T. longimanus shows a seasonally dioestrus pattern (Krishna \& Dominic) while in Nagpur, central India exhibits an aseasonal polyestrus (continuous) breeding pattern (Gopalakrishna).

There is an alternation of the two sides of genitalia, when one ovary shows corpus luteum during pregnancy, the contralateral ovary is not quiescent but shows folliculogenesis and at late pregnancy ovary shows fully formed Graafian follicle. The endocrine characteristic of the anomalous reproductive pattern in T. longimanus have not yet been studied. The present electron microscopic study was designed to elucidate the cytology of the pars distalis of female bat, T. longimanus during the physiology of reproduction.

\section{MATERIAL AND METHOD}

The emballonurid bat, T. longimanus (Hardwicke) was selected for the present study because of its unique reproductive habits. The specimens were collected from Nagpur, throughout the year representing different reproductive states. The specimens were brought to the laboratory alive. Mature females were separated from immature females after observing mammary glands and pelvic dugs.

For the electron-microscopic study, the intermediate and posterior lobes were separated from the pituitary gland and the isolated anterior pituitary was fixed in fresh icecold 3\% glutaraldehyde for three hours and then four hours in $0.1 \mathrm{M}$ cacodylate buffer. The tissues were washed in buffer and then post fixed for one to two hours in $1 \% 0.067$ M cacodylate-buffered osmium tetroxide. After dehydration with graded series of alcohol, the tissues were cleared in propylene oxide solution and embedded in Araldite resin which would be polymerized at $60^{\circ} \mathrm{C}$. Then, ultrathin sections from selected blocks were cut with glass knife and picked up on 400-mesh copper grids. Sections were double stained with $10 \%$ alcoholic uranyl acetate for $20 \mathrm{~min}$ and for $10 \mathrm{~min}$ in Reynold's lead citrate. The sections were examined under a JEM Jeol-100s electron microscope (Japan) at $80 \mathrm{KU}$ accelerating voltage and photographed.

\section{RESULTS}

The current concept of cell identification and differentiation in the mammalian pituitary gland is based on the activity of the Golgi-apparatus, the elaboration of secretory granules, liberation of the granules from the cell membrane, development of the ergastoplasm and morphology of the mitochondria. Beside this, the shape and the size of the cell, nucleus and the distribution and morphological features of the secretory granules are also taken into consideration. All these constitute visible changes which allow us to determine the state of the secretory activity of each of the adenohypophysial cell. The fine structure of the pars distalis of $T$. longimanus is studied during the different phases of the reproductive cycle. The present ultrastructural observations demonstrate the presence of six cell types in the pars distalis of non- pregnant and pregnant bats of T. longimanus.

\section{Somatotroph (STH-cells)}

These are the most prevalent cell type in the pars distalis of bat, T. longimanus. These are situated generally far from the capillaries. The pars distalis of estrus female shows that these cells are ovoid to polyhedral in shape and are found distributed throughout the pars distalis. The nucleus is irregular in shape with a little indentation and eccentrically placed, mostly euchromatic with varying amount of heterochromatin. A thin rim of heterochromatin is seen at the periphery of nucleus. Nucleolus is not visible. Mitochondria are spherical with lamellar cristae, distributed throughout the cytoplasm. Rough endoplasmic reticulum is not well developed and it is in the form of short tubular cisternae. Free ribosomes are seen scattered throughout the cytoplasm. Golgi complex is indistinct. The electron dense cytoplasm of these cells is filled with varying number of large, ovoid or markedly pleomorphic electron dense secretory granules. The size of granules ranges from 250$400 \mathrm{~nm}$ in diameter (Fig.1).

During pregnancy the fine structure of STH cells changes significantly. Mitochondria are relatively few during pregnancy and mitochondrial cristae are collapsed. In contrast to the inconspicuous Golgi complex in estrus, the Golgi zone of STH cell during pregnancy is well developed. Rough endoplasmic reticulum is not abundant in STH cells of pregnant bat. Secretory granules are ovoid to pleomorphic or irregular in shape with high electron density. They are large and small mostly seen towards one of the poles of cell. They are seen below the plasma membrane and near the Golgi complexes. Heterophagosomes are observed in the cytoplasm (Fig. 2). 

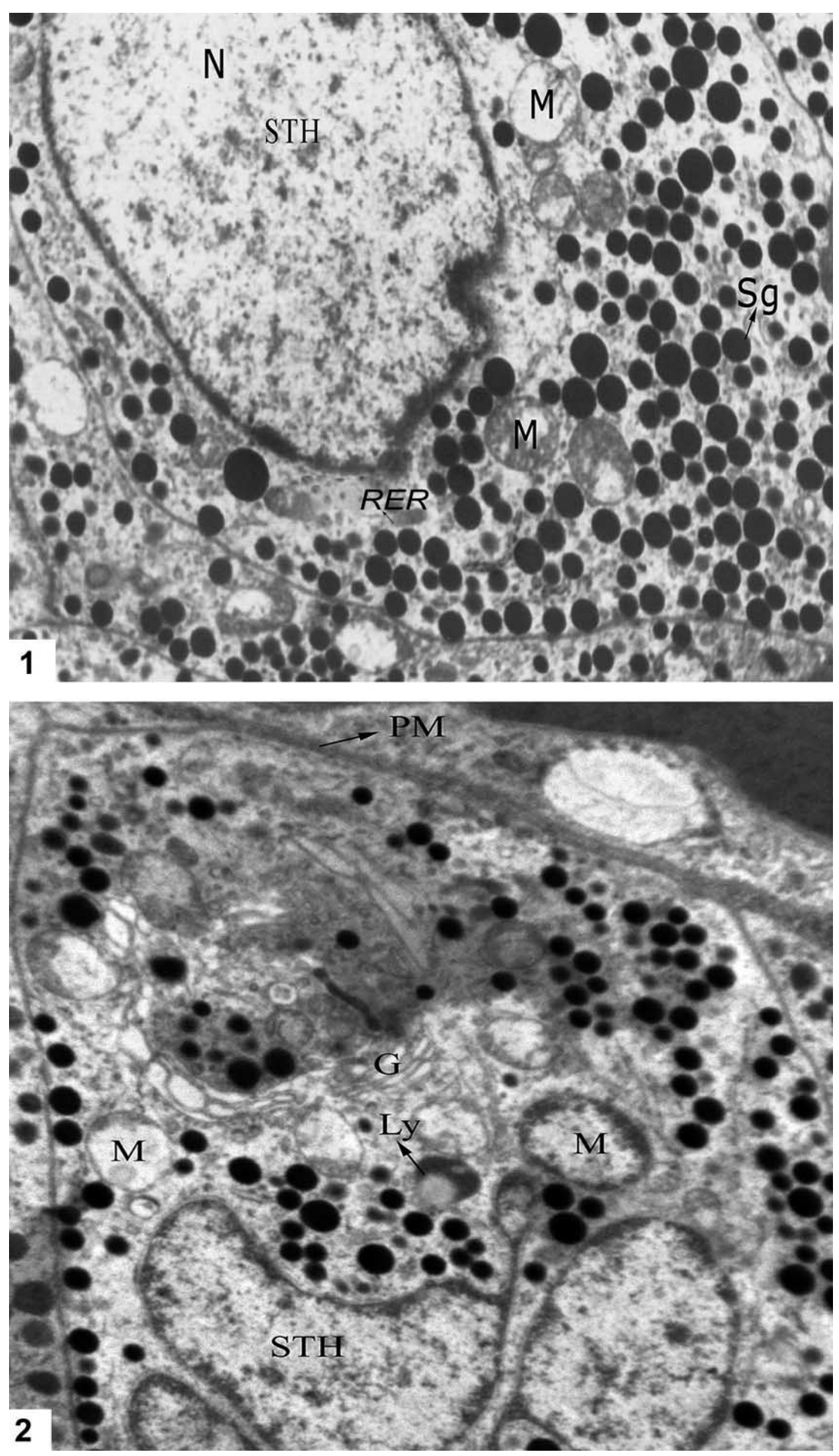

Fig. 1. Electron micrograph of STH cells in the pars distalis of female bat during estrus. Note irregular nucleus $(\mathrm{N})$, large number of electron dense round to ovoid secretory granules (Sg) and globular mitochondria (M) with lamellar cristae. X $10 \mathrm{~K}$.

Fig. 2. Electron micrograph of the STH cell during early pregnancy showing lobed nucleus $(\mathrm{N})$, spherical mitochondria (M) with lamellar cristae, well developed Golgi apparatus (G) with dilated cisternae and lysosome (Ly). Note large number of electron dense secretory granules $(\mathrm{Sg})$ mostly seen at periphery of the cells. X 12000 .
In pars distalis of bat, $T$. longimanus two types of STH cells are observed. One cell type corresponds to a medium sized cell with a large Golgi area and few granules while the other cell type observed corresponds to a large cell, the cytoplasm of which is filled with large secretory granules and contains a reduced Golgi area. The first cell type represents an active cell engaged in hormone secretion while the second cell type is in a reserve state. This aspect corresponds to so-called functional alternation phenomenon.

\section{Lactotroph (PRL-cells)}

LTH cells are easily recognizable with electron microscopy in this bat. The number of these cells varies in female during its reproductive activity such as pregnant and nonpregnant stage. During estrus, LTH cells are large, irregular in outline. Nucleus is eccentrical and indented. Heterochromatin flakes are distributed throughout cytoplasm and a rim of heterochromatin is seen attached to inner surface of nuclear membrane. Nuclear pores are visible. Mitochondria are spherical to rod shaped with lamellar cristae and are distributed throughout the cytoplasm. Some of the mitochondria are hypertrophied and cristae are collapsed. The rough endoplasmic reticulum is in the form of short and long tubular profiles dotted with ribosomes are seen scattered in the cytoplasm. Free ribosomes are distributed throughout the cytoplasm. Golgi zone is well developed and present near the nucleus. This zone is made up of number of Golgi complexes arranged in circle. Large number of electron dense secretory granules is present in close proximity to Golgi saccules. They are markedly pleomorphic or irregular in shape and measure 300-500 nm in diameter. These electron dense granules are seen mostly towards the apical cytoplasm, near or attached to the plasma membrane. No exocytosis is observed in the cell (Fig. 3). 
LTH cells in the pars distalis during early and mid- pregnancy are hypertrophied and granulated. Mitochondria are numerous and more or less same as in estrus bat. A well developed Golgi zone is situated towards one pole of cytoplasm as in estrus bat. Lysosomes and multivesicular bodies are also present in the cytoplasm. The electron dense granules are pleomorphic. Large number of secretory granules is seen scattered in the cytoplasm. The structure of cellular organelles indicates that the LTH cell shows high secretory activity during early phases of pregnancy (Figs. 4, 5). The most conspicuous ultrastructural features of LTH cells during late pregnancy is a well developed rough endoplasmic reticulum. It is mostly concentrated in the apical cytoplasm. Mitochondria are round to rod shaped with lamellar cristae are distributed in the cytoplasm. The electron dense granules are pleomorphic. These secretory granules are large in number and are distributed throughout the cytoplasm (Fig. 6).

\section{Corticotroph (ACTH-cells)}

These cells are found either singly or in groups. These are not very abundant and correspond to a small number of adenohypophysial cell populations. These cells are elongated or angular with long cytoplasmic processes with eccentric nucleus. Nucleus is large, irregular with marked indentations occupying major part of the cytoplasm. Heterochromatin is in the form of granules distributed throughout the nucleoplasm. Mitochondria are round with lamellar cristae, distributed throughout the cytoplasm. Some mitochondria are hypertrophied with collapsed cristae. Golgi apparatus is not well developed. Rough endoplasmic reticulum is in the form of elongated tubular profiles arranged parallel to one another and is distributed throughout the cytoplasm. Ribosomes are more and lying free in the cytoplasm. Secretory granules are spherical or ovoid shaped and exhibit variation in electron density. The diameter of granule is $200-250 \mathrm{~nm}$ (Fig. 7).

\section{Thyrotroph (TSH cells)}

TSH cells in estrus bat are elongated, polygonal or triangular in shape with large cytoplasmic processes. Nucleus is irregular in outline and shows indentations. It is placed eccentrically, clumps of heterochromatin are seen distributed in nucleoplasm. A rim of heterochromatin is adherent to the inner surface of nuclear membrane. Mitochondria are distributed throughout the
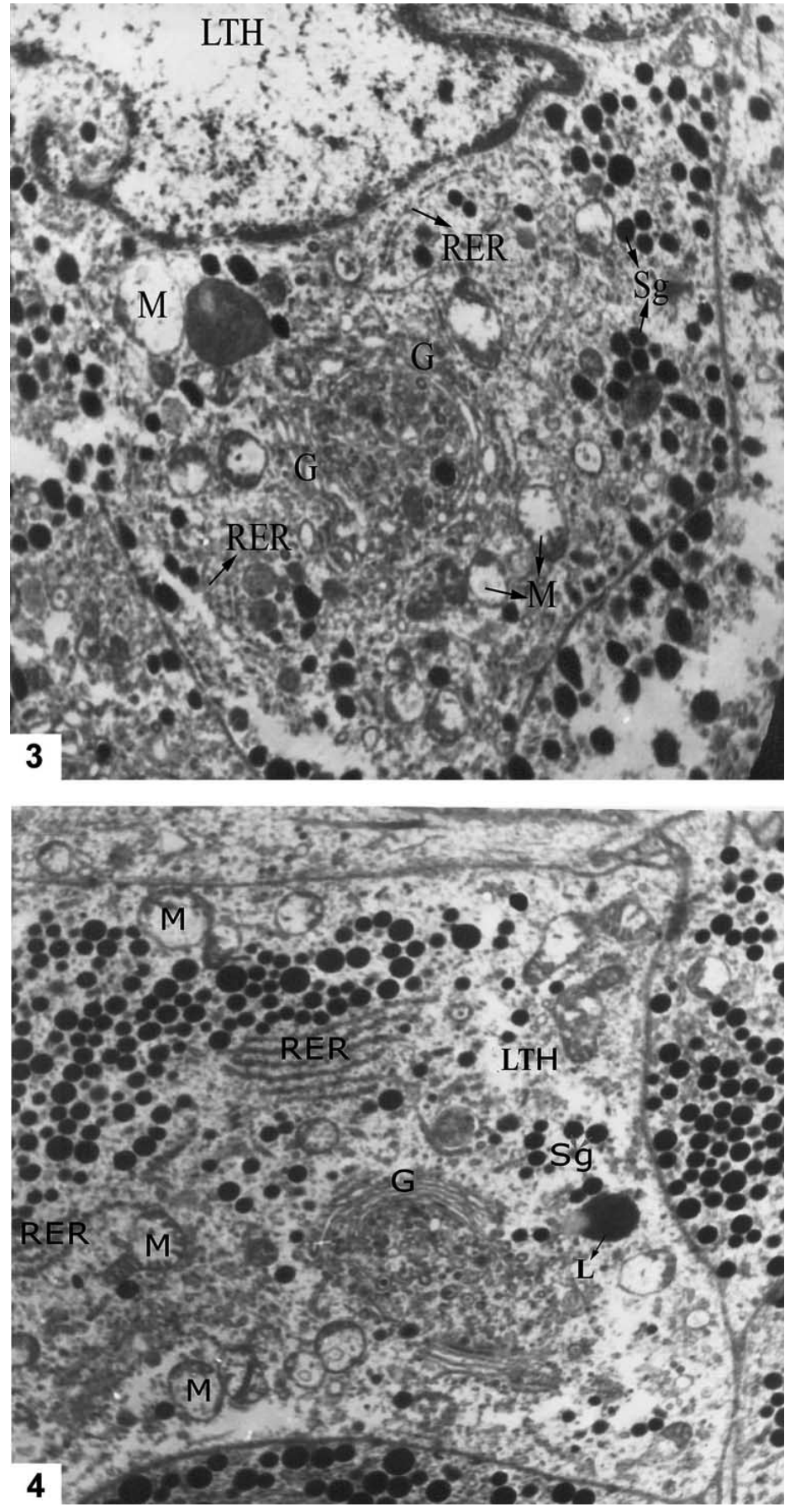

Fig. 3. Electron micrograph of the LTH cell during estrus. Note indented nucleus $(\mathrm{N})$, spherical to oval mitochondria $(\mathrm{M})$ with lamellar or collapsed cristae and well developed Golgi apparatus $(\mathrm{G})$ with stacks of dilated Golgi saccules arranged in semicircle contains many immature secretory granules. Cisternae of rough endoplasmic reticulum (RER) are tubular and electron dense secretory granules $(\mathrm{Sg})$ are pleomorphic and are seen below the plasma membrane. X 10000.

Fig. 4. Electron micrograph of the LTH cell during early pregnancy. Note well developed Golgi apparatus (G), hypertrophied mitochondria (M) and parallely arranged cisternae of rough endoplasmic reticulum (RER). Note lysosome (Ly) and secretory granules (Sg) are pleomorphic. X 12000. 

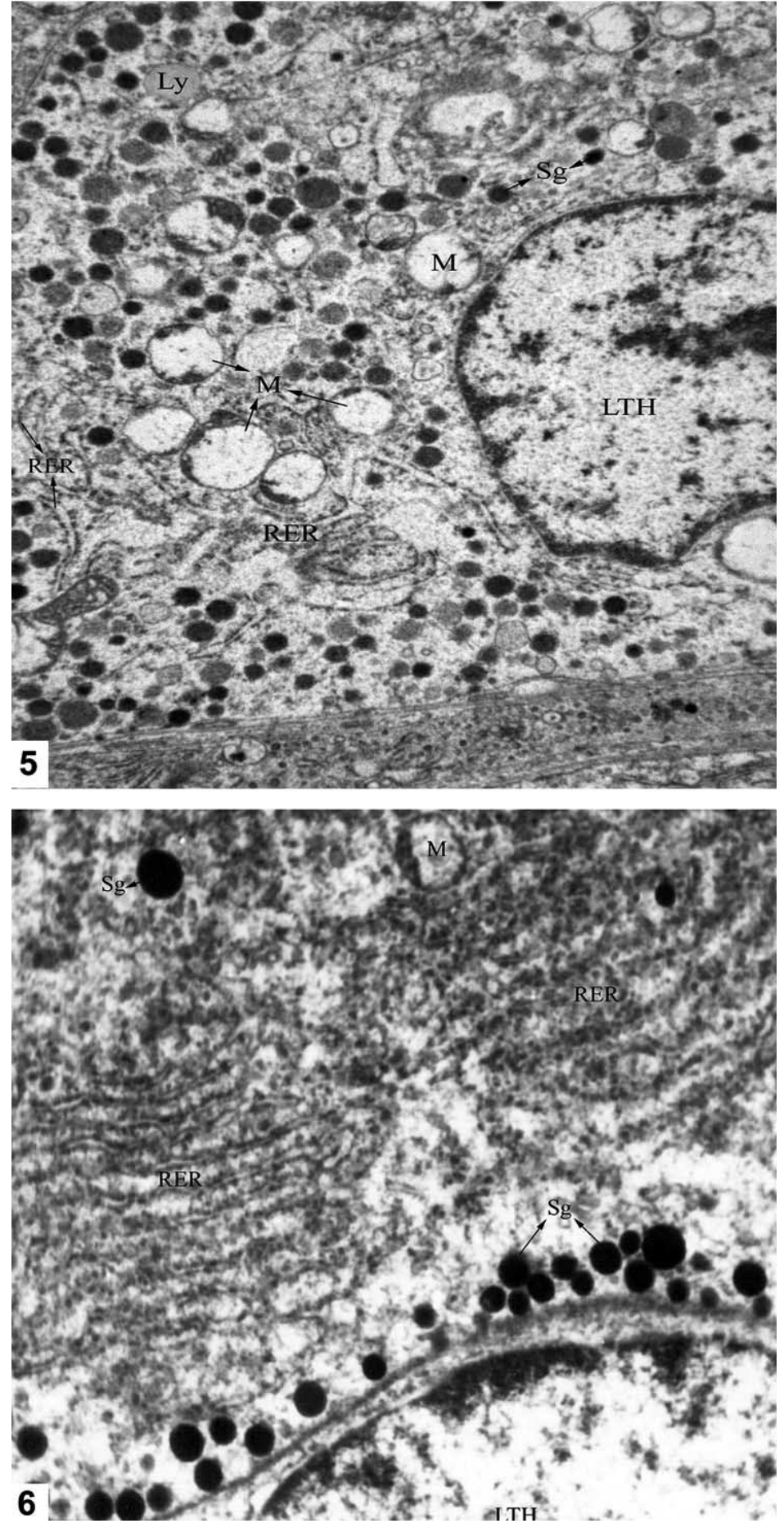

Fig. 5. Electron micrograph of the LTH cell during mid-pregnancy showing nucleus $(\mathrm{N})$, hypertrophied mitochondria $(\mathrm{M})$ with collapsed cristae, tubular cisternae of rough endoplasmic reticulum, lysosome (L) and less electron dense secretory granules (Sg). X 12000.

Fig. 6. Electron micrograph of part of the LTH cell during late pregnancy showing nucleus $(\mathrm{N})$ with rim of chromatin material, parallely arranged tubular cisternae of rough endoplasmic reticulum (RER), and spherical mitochondria (M) with lamellar cristae. Note Secretory granules (Sg) are arranged just below the plasma membrane X 12000 . cytoplasm. They are hypertrophied with collapsed cristae. In contrast to TSH cells of estrus bat, the TSH cells of pregnant bats contain a well developed endoplasmic reticulum. Golgi apparatus is not well developed in TSH cells of estrus and pregnant bats. Secretory granules are small, somewhat spherical and vary in electron density. It measures 150-200 $\mathrm{nm}$ in diameter. In sparsely granulated cells, they show a peripheral distribution. In more granulated cells, they are scattered throughout the cytoplasm (Figs 8, 9).

\section{Gonadotrophs (FSH and LH cells)}

In the present study, the identification and characterization of the FSH cell is based on morphological features of the cellular constituents such as secretory granules, ergastoplasm, Golgi apparatus and mitochondria. The characteristic changes occurring in these cells during the various physiological states (estrus and different stages of gestation) also confirm characterization of these cells. FSH cells in the pars distalis of estrus bats are large ovoid to polyhedral. Euchromatic nucleus is irregular in outline and shows indentations. Heterochromatin in the form of chromatin granules are seen scattered throughout the nucleoplasm. A thin rim of heterochromatin is seen in the periphery of nucleus. Mitochondria are hypertrophied and are present in the Golgi zone. Elements of Golgi complex outline a cytoplasmic area nearly as large as the nucleus. Associated with dilated saccules, large number of small vesicles is present. Secretory granules are spherical, variable size and electron density and are distributed throughout the cytoplasm (Fig. 10).

The fine structure of FSH cells changes during pregnancy. Mitochondria are spherical or rod shaped with lamellar cristae. Some are with collapsed cristae. Rough endoplasmic reticulum is in the form of lamellar or tubular cisternae studded with ribosome. Secretory granules are electron dense and variable in size. They are distributed in apical cytoplasm (Fig. 11). As pregnancy advances, cytoplasm appears vacuolated because of dilation of rough endoplasmic reticulum. Endoplasmic reticulum characteristically occurs in a vesicular form of varied sizes and irregular shapes. These dilated cisternae are sparsely dotted with ribosomes and are distributed throughout the cytoplasm. The lumina of cisternae are filled with less osmiophilic material. The hypertrophy of FSH cells during late 
pregnancy is associated with the filigreed cytoplasmic pattern giving a bizarre appearance (Fig. 12). In contrast to FSH cells of estrus bats, the FSH cells contain inconspicuous Golgi complex in pregnant bat. Lysosomal bodies and multivesicular bodies containing 3-4 granules are also observed in the cytoplasm. A very few electron dense granules are present. They are scattered throughout the cytoplasm and more towards the apical cytoplasm. The size of secretory granules ranges from 200 to $400 \mathrm{~nm}$ in diameter during different phases of the reproductive cycle. Thus, the FSH cell shows well developed cell organelles such as mitochondria, Golgi and rough endoplasmic reticulum during pregnancy. This indicates that the FSH cells are active during pregnancy and elaborate large amounts of follicle stimulating hormone.

During early part of gestation, LH gonadotroph cells are large polygonal with large bilobed nucleus occupying maximum part of the cytoplasm. Heterochromatin flakes are distributed throughout the nucleoplasm. A thick rim of heterochromatin and two prominent nucleoli are seen below the nuclear membrane. Structure of mitochondria is more or less identical during the course of pregnancy. Mitochondria are round with lamellar cristae distributed throughout the cytoplasm. Some mitochondria are hypertrophied with loss of cristae. The cisternae of rough endoplasmic reticulum are dilated and are distributed throughout the cytoplasm, but more towards the nucleus. These dilated cisternae are studded with ribosomes. Because of dilation of rough endoplasmic reticulum, it gives vacuolated appearance to the cytoplasm. Golgi zone is present juxtanuclear in position. Golgi complex is made up of 7-8 Golgi saccules associated with small vesicles. In the region of Golgi, small granules are observed. Golgi saccules are curved and dilated at the ends. Heterophagosomes are observed in the cytoplasm. Large number of secretory granules of varying electron density is observed distributed throughout the cytoplasm. These secretory granules measure 200-300 nm in diameter (Fig. 13).

Hypertrophied LH gonadotroph cells in the pars distalis of pregnant bat (late pregnancy) show well developed endoplasmic reticulum.
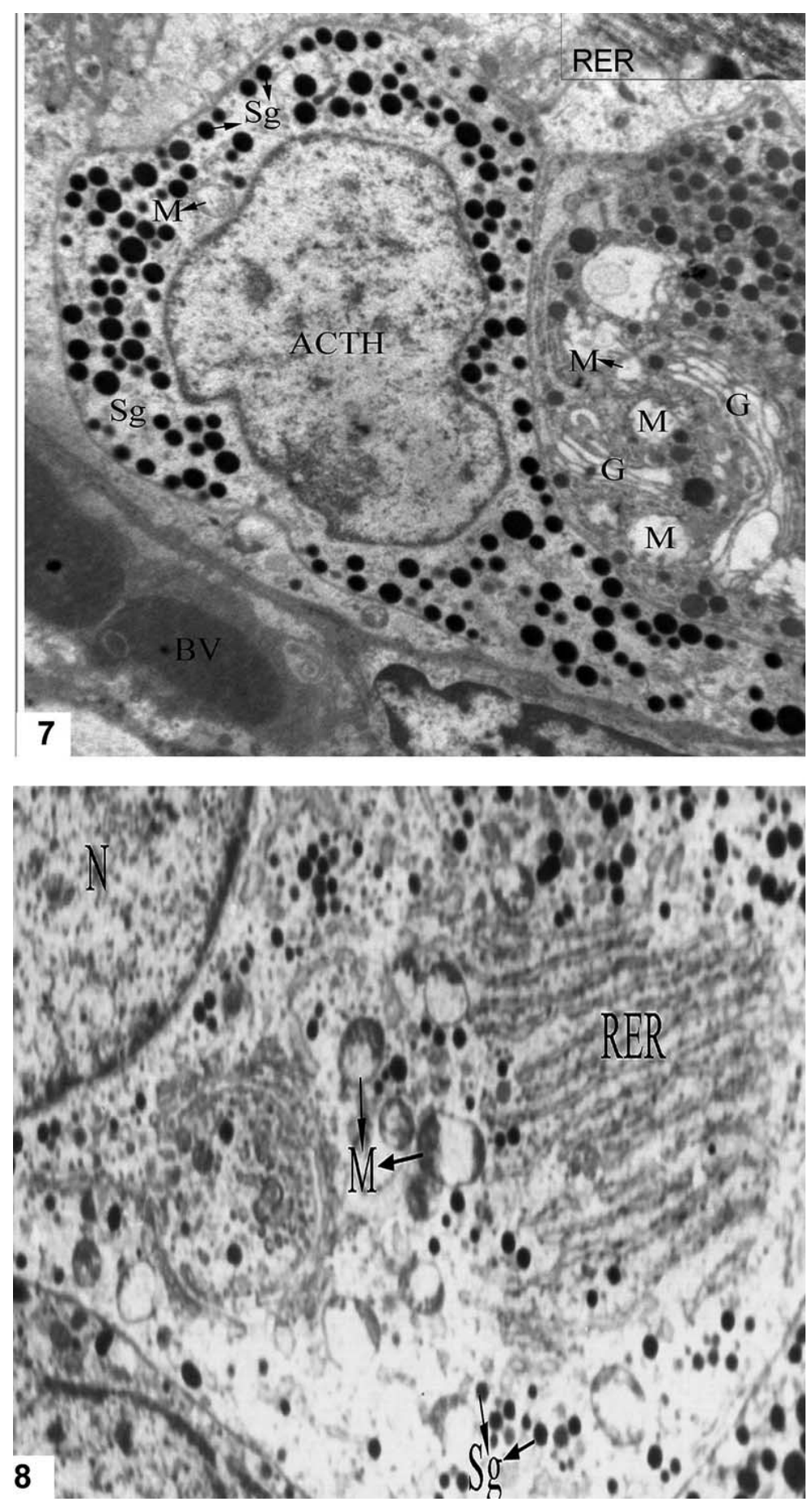

Fig. 7. Electron micrograph of the triangular ACTH cell during early pregnancy showing indented nucleus $(\mathrm{N})$ with rim of heterochromatin below nuclear membrane. Spherical mitochondria (M) and electron dense secretory granules $(\mathrm{Sg})$ are distributed throughout the cytoplasm. Cisternae of rough endoplasmic reticulum (RER) are also observed. X 8000.

Fig. 8. Electron micrograph of TSH cell during early pregnancy. Note the angular shape of TSH cell with irregular, enlarged nucleus $(\mathrm{N})$, round to oval shaped mitochondria $(\mathrm{M})$ and stack of parallel cisternae of rough endoplasmic reticulum (RER). Cytoplasm is filled with large number of small sized secretory granules (Sg). X 8000 . 

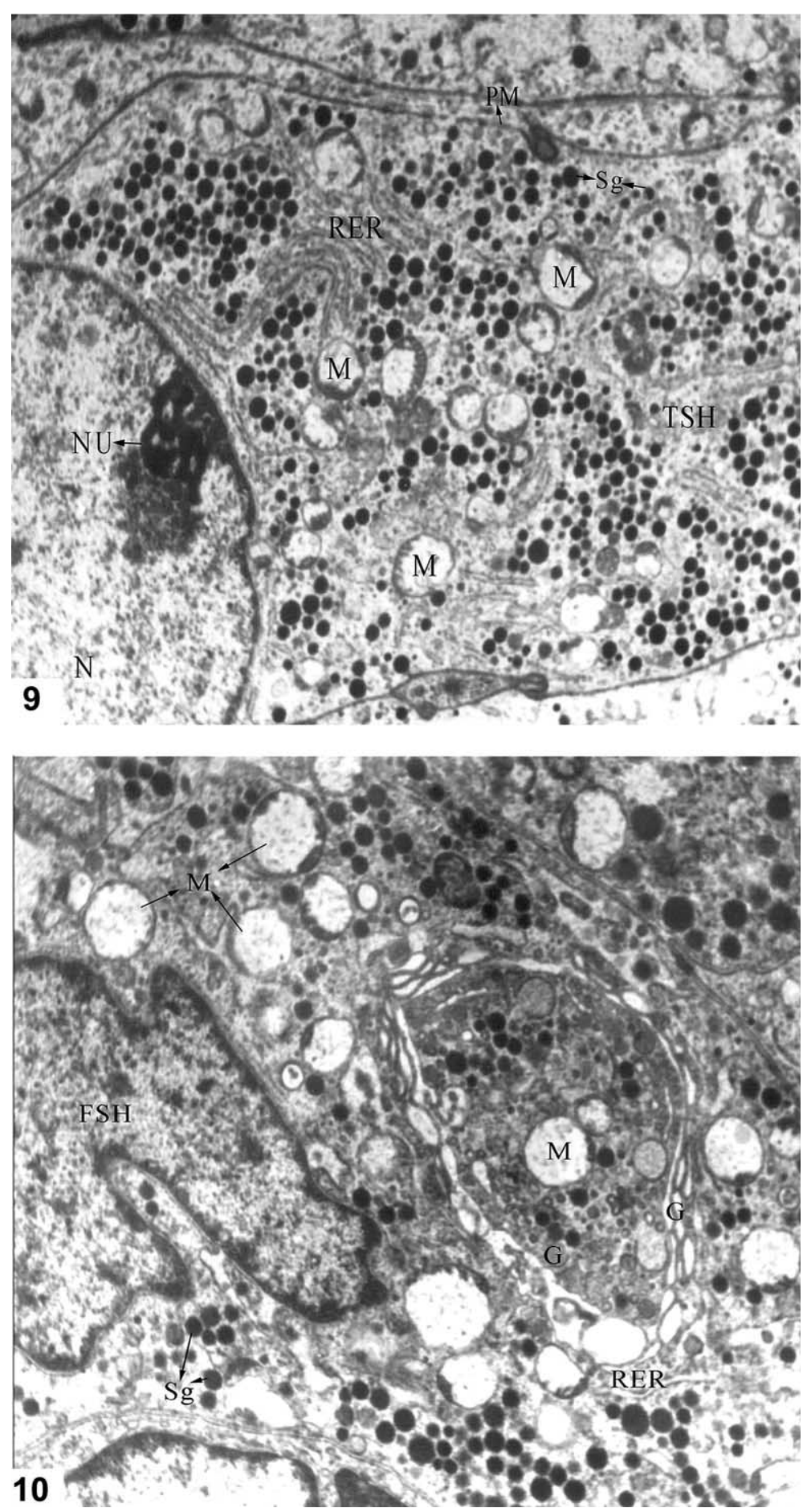

Fig. 9. Electron micrograph of the angular TSH cell during mid-pregnancy. Note the presence of indented nucleus $(\mathrm{N})$ with nucleolus, hypertrophied mitochondria (M) with collapsed cristae, rough endoplasmic reticulum (RER) and electron dense secretory granules (Sg). X 8000 .

Fig. 10. Electron micrograph of the FSH cell during estrus. Note indented nucleus $(\mathrm{N})$, hypertrophied mitochondria (M) with collapsed cristae, tubular cisternae of rough endoplasmic reticulum (RER), secretory granules ( $\mathrm{Sg}$ ) and hypertrophied Golgi apparatus $(\mathrm{G})$ consists of dilated saccules and small vesicles forming a circlet near the nucleus. X $12 \mathrm{~K}$
The profiles of rough endoplasmic reticulum occupy a large part of the cytoplasm, displacing other cell constituents. The cisternae of rough endoplasmic reticulum are arranged in parallel arrays. In some cells, cytoplasm is extremely vacuolated is due to dilation of cisternae of rough endoplasmic reticulum. The hypertrophy of $\mathrm{LH}$ cells is associated with the filigreed cytoplasmic pattern giving a highly bizarre appearance. Ribosomes are distributed throughout the cytoplasm. Golgi apparatus is indistinct. The secretory granules are less in number and are distributed towards the periphery of the cell. During pregnancy, LH cells show gradual hypertrophy and show marked development of mitochondria, Golgi and rough endoplasmic reticulum. Thus, these cells are very active and elaborate large amounts of luteinizing hormone during the pregnancy (Fig. 14).

\section{DISCUSSION}

Electron microscopic study offers the advantage of revealing the state of activity of the cells and their morphological features in a precise manner, which allows formulating the criteria for their functional analysis. In conjunction with our knowledge of the ultrastructure of the mammalian pituitary gland (Herlant, 1964; Harris \& Donovan, 1966; Nunez et al., 1980; Bhiwgade et al.; Muniz et al.; Singh \& Krishna, 1994, 1997), the present ultrastructural observations demonstrate the presence of six cell types in the pars distalis of adult female emballonurid bat, $T$. longimanus. The increase in nuclear size, enlargement of nucleoli and hypertrophy of organelles and nature of secretory granules of the cells have taken as the indicators of stimulation and increased synthetic activity.

\section{Somatotroph (STH-cells)}

Ultrastructural characteristics of STH cells of Indian fruit bat, $R$. leschenaulti have been studied by Bhiwgade et al. These cells are round to oval in shape with centrally placed round nucleus. The secretory granules are numerous, uniform, round and very dense about 350-400 $\mathrm{nm}$ in diameter. The Golgi apparatus is inconspicuous and mitochondria are round and 
scattered in the cytoplasm. In S. heathi, Singh \& Krishna (1994), reported dense secretory granules ranging from 240 to $480 \mathrm{~nm}$ in diameter, round mitochondria and Golgi apparatus in the STH cells.

In Hipposideros lankadiva (Seraphim, 2004), STH cells are round to oval with eccentrically placed nucleus. The secretory granules are numerous, mostly round to oval with uniform electron density. The well developed Golgi, endoplasmic reticulum and small amount of secretory granules indicate a cell under vigorous synthetic activity while those filled with secretory granules with reduced Golgi complex suggest reserve or storage state of cells, supporting the present observations. The oval to round STH cells in pars distalis is reported in Miniopterus schreibersii fuliginosus (Mikami, et al., 1988). In general secretory granules in the STH cells of bats are dense, membrane enclosed and from 350-400 nm in diameter (Herlant, 1962, 1963; Azzali). In T. longimanus, the diameter of secretory granules ranges from $250-400 \mathrm{~nm}$. The $\mathrm{STH}$ cells thus, identified in the pars distalis of $T$. longimanus are comparable with STH cells identified and reported in the other species of bats confirming our observations (Bhiwgade et al., Singh \& Krishna, 1994, Seraphim).

\section{Lactotroph (PRL-cells)}

The ultrastructure features of LTH cells in the pars distalis of pregnant bats differ from that of the other cells of the estrus bat. These cells are hypertrophied and granulated during pregnancy. Mitochondria are numerous, Golgi apparatus and rough endoplasmic reticulum are well developed. The electron dense granules are pleomorphic and are seen scattered in cytoplasm. The size of granules ranges from 300-500 nm diameter. The most conspicuous ultrastructural feature of LTH cells during late pregnancy is well developed endoplasmic reticulum. The structure of cell organelles indicates that the LTH cells show high secretory activity during different phases of pregnancy. Lysosomes and multivesicular bodies which were not observed during early part of gestation are observed in the LTH cells during late pregnancy, thus indicating digestion of excess secretory material.
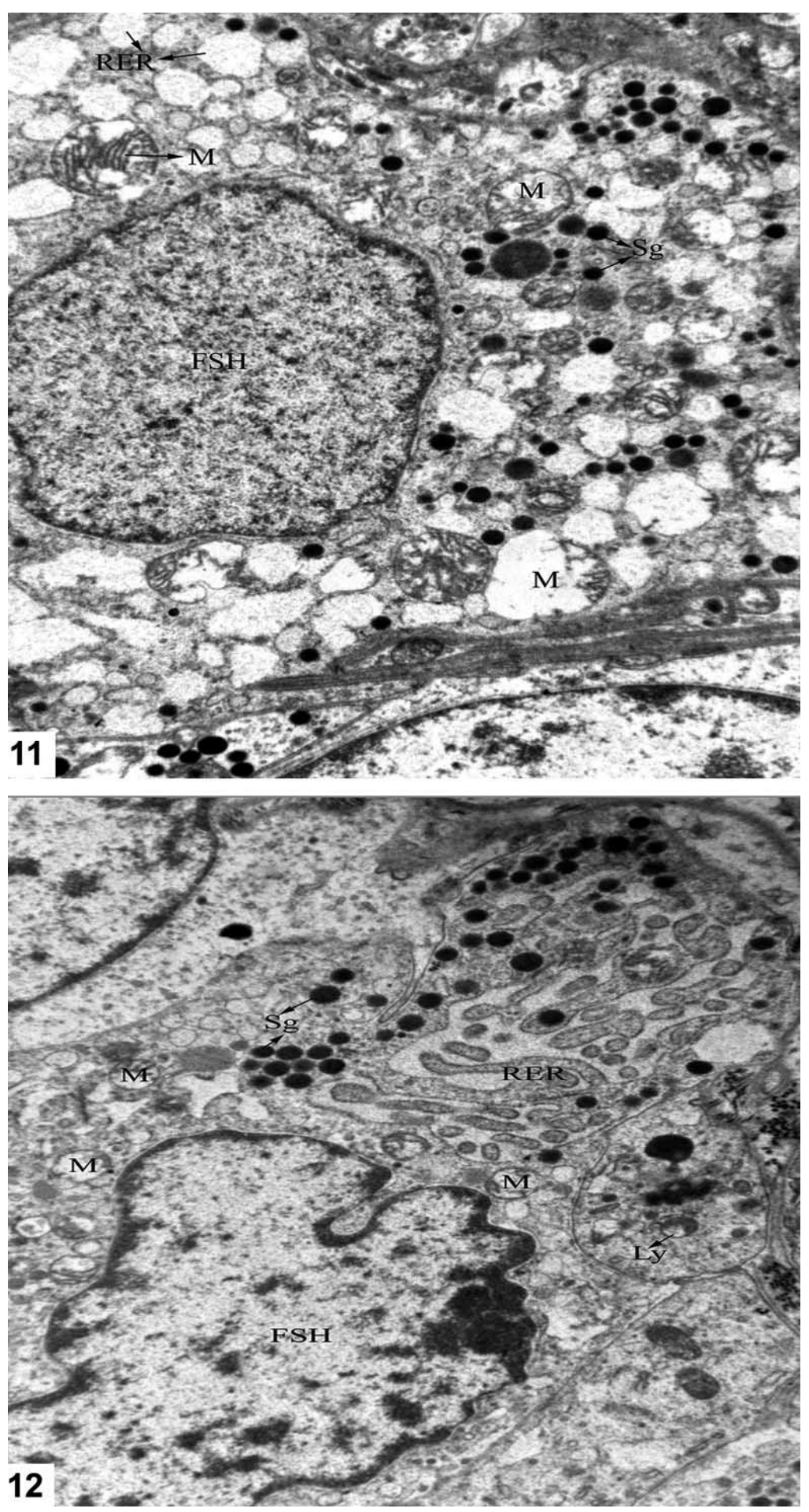

Fig. 11. Electron micrograph of the FSH cell during mid-pregnancy showing nucleus $(\mathrm{N})$, hypertrophied mitochondria $(\mathrm{M})$ with lamellar or collapsed cristae, rough endoplasmic reticulum (RER) is in the form of dilated cisternae and a very few secretory granules. X 12000

Fig.12. Electron micrograph of the FSH cell during late pregnancy. Note indented nucleus $(\mathrm{N})$ with nucleolus, globular mitochondria (M) with lamellar cristae, dilated cisternae of rough endoplasmic reticulum (RER) and electron dense secretory granules (Sg) at the periphery of the cell. X 12000 

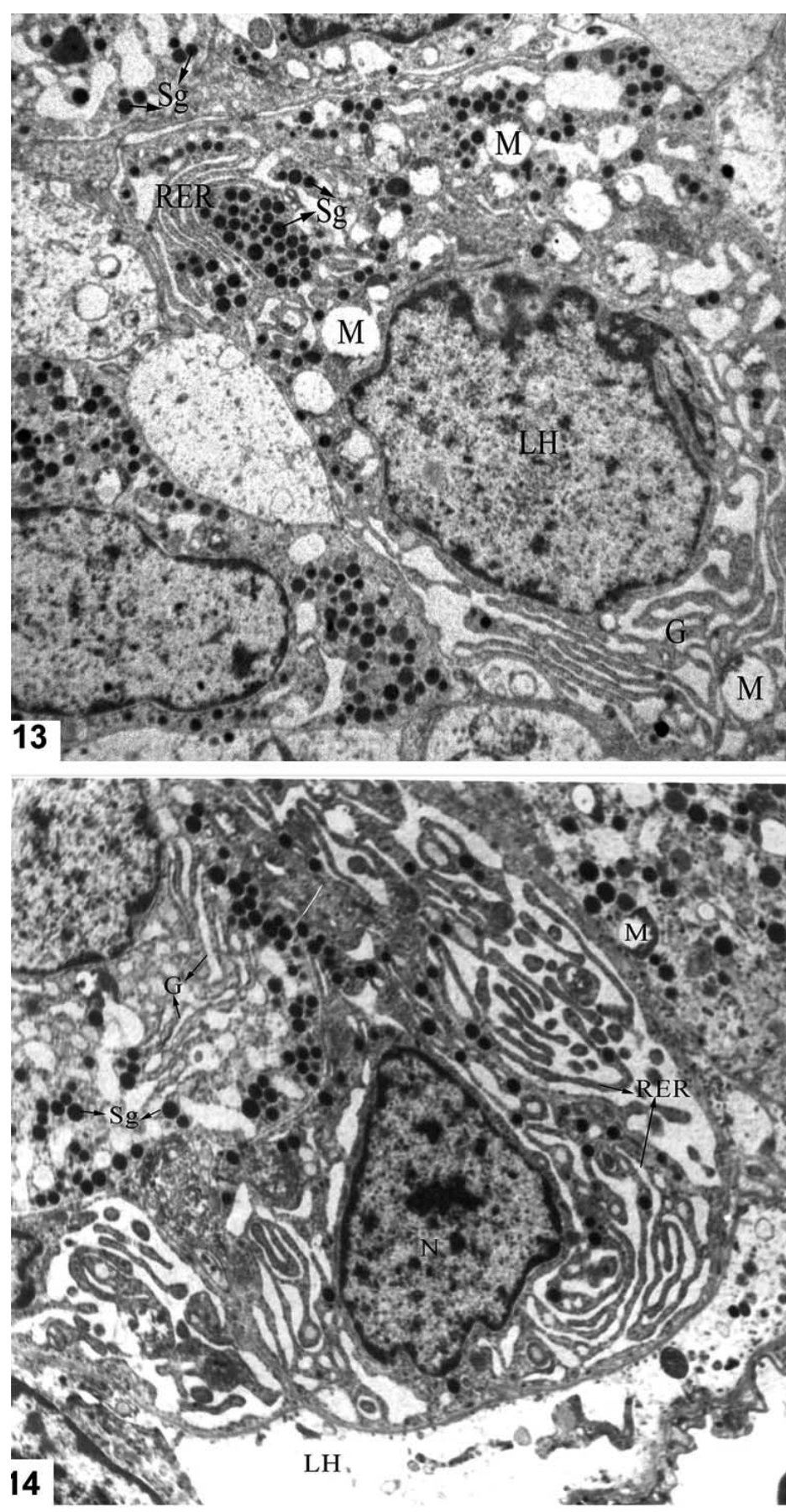

Fig. 13. Electron micrograph of the LH cell during mid-pregnancy showing the indented nucleus $(\mathrm{N})$, hypertrophied Golgi apparatus $(\mathrm{G})$, tubular and dilated cisternae of granular endoplasmic reticulum (RER), hypertrophied mitochondria $(\mathrm{M})$ with collapsed cristae and small secretory granules $(\mathrm{Sg})$ distributed towards the periphery of the cell. X 6000.

Fig. 14. Electron micrograph of the LH cell during late pregnancy. Note the irregularly shaped LH cell, with eccentrically placed nucleus $(\mathrm{N})$, extreme dilation of endoplasmic reticulum (RER) giving bizarre appearance, hypertrophied mitochondria (M) and very few small secretory granules (Sg) scattered throughout the cell. Golgi is well developed and present near the nucleus. X 8000.
Bhiwgade et al. reported that the LTH cells are characterized by the largest secretory granules, well developed endoplasmic reticulum and numerous mitochondria in the cytoplasm. They further reported that an accumulation of secretory material in the PRL cells associated with the retention of milk following the removal of litter contributes favorably for identification of the prolactin in bat. An accumulation of secretory granules in PRL cells after $8 \mathrm{hrs}$ of nonsuckling and decrease of granules prompted by 10 minutes of suckling has been confirmed.

In S. heathi, Singh \& Krishna (1994) reported numerous mitochondria, dilated endoplasmic reticulum and extensive Golgi complex, large number of secretory granules in the LTH cells. Ishibashi and Shiino (1989) identified the LTH cells in the pars distalis of Pipistrellus abramus. These cells show morphologically active features in pregnant and lactating females and have a tendency to contain smaller secretory granules. In $H$. lankadiva the LTH cells in the pars distalis show hypertrophied mitochondria with lamellar cristae, dilated rough endoplasmic reticulum and well developed Golgi apparatus. The secretory granules are arranged along the plasma membrane.

Muniz et al. reported prolactin granules of variable shapes and electron density. The degranulation of LTH cells of pregnant female of M. myotis is observed under experimental conditions, which display greatly increased development of the rough endoplasmic reticulum, Golgi apparatus, a large number of lysosomes. The higher concentration of the LTH prolactin cells for mammary growth and milk secretion during gestation and lactation has been reported (Harris \& Donovan, 1966; Austin \& Short, 1972).

The mammotrophs occupy the pars distalis of hibernating bat, P. abramus during pregnancy and lactation suggesting the elevated prolactin content during this period (Ishibashi \& Shiino). The proliferation activity of mammotrophs in female bat was observed during pregnancy and lactation (Kawamoto, 2003). The morphometrical activity and PRL level were mostly low during follicular development and the early implantation and this activity and PRL level increases after implantation (Anthony, 2000).

The ultrastructural observations on LTH cells showed that size of secretory granules vary from 
species to species (Richardson). The size of secretory granules in bat, $M$. myotis ranges from $170-550 \mathrm{~nm}$ diameter (Herlant, 1963); V. savi and V. piccolo from 700-800 nm diameter (Azzali); R. leschenaulti from 400-600 nm diameter; S. heathi, from 300-600 nm diameter (Singh \& Krishna, 1994) and M. myotis from 180-510 nm diameter (Muniz et al. 1991). In the present study the size of secretory granules in $T$. longimanus ranges from 300 to $500 \mathrm{~nm}$ diameter. The LTH cells, thus identified in pars distalis of nonpregnant and pregnant bat of $T$. longimanus with electron microscopy are comparable with LTH cells of the other species of bats confirming our observations.

Apart of lactogenic function, LTH cells are also luteotrophic in function in bats, M. schreibersii (Peyre \& Herlant, 1963; Herlant, 1968) Macrotus californicus (Bleier, 1975); H. lankadiva (Seraphim) and T. melanopogon (Badwaik, 1988). Singh \& Krishna (2000) observed two peaks of progesterone concentration during the reproductive cycle coincide with two pregnancies in T. longimanus. Since T. longimanus invariably bears only one conceptus at a time, the variation in progesterone concentration during pregnancy appear to depend on stages of embryonic development.

In the present study, LTH cells in par distalis of pregnant bat, $T$. longimanus, which is a continuous breeder, are synthetically active and elaborate large quantity of prolactin during pregnancy. This hormone may be stimulating luteal cells of corpus luteum to synthesize progesterone. The ultrastructural features of luteal cells in Taphozous indicate that these cells are steroidogenically active during pregnancy (Nerkar \& Gadegone, 2007), suggesting that the LTH cells are luteotrophic in this species of bat as observed in other bat species. Our findings correlate with the findings of other workers on bats.

\section{Corticotroph (ACTH cells)}

ACTH cells are elongated or angular found either singly or in groups in pars distalis of $T$. longimanus during pregnancy. Mitochondria are round with lamellar cristae. Rough endoplasmic reticulum is in the form of elongated and short tubular profiles. Golgi complex is inconspicuous. The spherical or ovoidal secretory granules $(200-250 \mathrm{~nm}$ in diameter) of variable electron density are present just below the plasma membrane. The size and peripheral arrangement of secretory granules are characteristic of ACTH cell of $T$. longimanus.

Similar ultrastructural characteristics of ACTH cells are reported in S. heathi (Singh \& Krishna, 1994, 1997); R. leschenaulti (Bhiwgade et al.); H. lankadiva (Seraphim). The ACTH cells were hypertrophied and became largest cells in the pars distalis of $R$. leschenaulti after the adrenalectomy and metapyrone treatment. The mitochondria, rough endoplasmic reticulum and Golgi apparatus are poorly developed in normal state. Secretory granules of about $100-150 \mathrm{~nm}$ in diameter but become more extensive after adrenalectomy. In S. heathi, Singh \& Krishna $(1994,1997)$, revealed the presence of small secretory granules of about $100-190 \mathrm{~nm}$ in diameter. The nuclei were ovoid to irregular. The mitochondria with spaced cristae are also observed. In M. schreibersii fuliginosus, the large round or polygonal ACTH cells are reported in rostroventral and ventrolateral region of the pars distalis (Mikami et al.). Ultrastructural characteristics of the ACTH cells i.e. peripheral arrangement of small sized secretory granules along the plasmalemma correspond to those reported in rat (Nakayama et al., 1969; Siperstein \& Miller, 1970); rabbit (Cameron \& Foster, 1972); cow (Mikami, 1970) and mink (Murphy \& James, 1976) supporting the present observations. The Malayan flying bat, Pteropus vampyrus, Reeder et al. (2006) reported that the bats restraint stress for 15-60 minutes results in a significant increase in plasma levels of ACTH and glucocorticoid. ACTH levels quickly returns to baseline following restraint, whereas glucocorticoid levels remains elevated for at least 30 minutes after restraint ended. Widmaier et al. (1994) reported that the chiropteran adrenal gland is hypersensitive to ACTH or possess active intracellular steroidogenic mechanism. They conclude that the bat possesses a stress response and the high constitutive and stress induced level of glucocorticoids in the Megachiroptera are unique among the mammals.

Although there are many different neuroendocrine components involved in regulating reproduction and the response to changing environment the hypothalamic-pituitaryadrenal (HPA) axis and the hypothalamic-pituitary gonadal (HPG) axis are particularly important (Reeder \& Kramer, 2005; Reeder et al.). The ACTH regulates the synthesis and release of glucocorticoids in the adrenal cortex. Glucocorticoids hormones (cortisol and corticosterone) are important regulators of energy balance and elevations in glucocorticoid hormones are considered a hallmark of the vertebrate stress response (Reeder \& Kramer, 2005). The HPA and HPG axes interact with one another in complex ways and in part, serve to regulate behaviour and fertility (DeVries, 2002; Viau, 2002). Ultrastructural features of ACTH cells and adrenocortical cells of T. longimanus during pregnancy (Nerkar \& Gadegone, 2009) suggest that these cells are metabolically active and may be involved in the reproductive processes and management of stress, bat is undergoing during pregnancy.

\section{Thyrotroph (TSH cells)}

TSH cells during pregnancy show similar ultrastructural features that observed in the TSH cells during 
estrus, except well developed rough surfaced endoplasmic reticulum. It is in the form of array of elongated, tubular or lamellar cisternae frequently localized at one pole or periphery of the cell. The profiles of cisternae are parallel to one another or curved. Free ribosomes are seen scattered in the cytoplasm. Golgi is inconspicuous. The small secretory granules are 150-200 $\mathrm{nm}$ in diameter, in varying electron density are scattered throughout the cytoplasm or show peripheral distribution. Thus, ultrastructural features of TSH cells during estrus and pregnancy suggest that these cells elaborate large quantity of thyrotrophic hormones.

In S. heathi, TSH cells showed the presence of a few secretory granules which ranged in diameter from 100$160 \mathrm{~nm}$. The cytoplasm contained rounded to elongated mitochondria, free ribosomes and poorly developed Golgi complex (Singh \& Krishna, 1994). In H. lankadiva, Seraphim reported angular TSH cells in the pars distalis of estrus bat. The TSH cells show fine secretory granules which are relatively uniform in size (100 to $200 \mathrm{~nm}$ in diameter), small Golgi arranged in circular array and rod shaped mitochondria and several stacks of rough surfaced endoplasmic reticulum. The size of secretory granules is the characteristic of TSH cell which is of 150-200 nm diameter is also reported in the TSH cells of T. longimanus.

Bhiwgade et al. presented most convincing evidence for the presence of TSH cells in anterior pituitary of bat, $R$. leschenaulti by surgical and chemical thyroidectomy. The experiments resulted in hypertrophied TSH cells containing a small saccular dilations of rough endoplasmic reticulum studded with ribosome in the cytoplasm. Golgi complex and mitochondria are hypertrophied. The above findings provide direct evidence for the existence of TSH cells in the bat pituitary. Our observations are supported by many research workers on bats.

In the present study, TSH cells exhibit the presence of well developed Golgi apparatus, hypertrophied mitochondria, extreme dilation of cistenae of rough surfaced endoplasmic reliculum and large number of secretory granules indicates increased synthetic and metabolic activity of the TSH cells during estrus and pregnancy. The ultrastructural features of thyroid gland of T. longimanus during estrus and pregnancy indicate that the thyroid is synthetically very active (Nerkar \& Gadegone, 2009). Thus, the active TSH cells during estrus and pregnancy may be activing thyroid gland to produced large quantities of thyroxines which is necessary for normal transition from the reproductively inactive to active condition and development and growth of embryo of this species of bat, which is a continuous breeder.

\section{Gonadotrophs (FSH and LH cells)}

Several researchers have shown by electron microscopy (Farquhar \& Rinehart, 1954a; Purves, 1961) that morphological differences between FSH and LH producing cells exist. Herlant (1963, 1964, 1968), Azzali and Bhiwgade et al. studied cytological variations in gonadotrophs in different species of bats under various physiological conditions. They have differentiated the gonadotrophs into two distinct entities, the FSH and $\mathrm{LH}$ secreting gonadotrophs. According to Bhiwgade et al. (1989) the variations observed in the electron density of the secretory granules is sufficient to differentiate two types of gonadotrophs. These cells also differ in their cytoplasmic organelles and do not show similar changes under altered conditions such as estrus, pregnancy and lactation.

The present ultrastructural studies on par distalis from non pregnant and pregnant bats, $T$. longimanus point to the existence of two types of gonadotrophs in bats. The FSH-secreting cells described in bats correspond to the presumptive rat FSH cells of Nakane (1970), bat FSH cells of Herlant (1964) and mink FSH cells of Murphy \& James. The LH gonadotrophs in bats correspond to the LH cells of Nakane, gonadotrophs of Rennels et al. (1971) and LH cells of Herlant (1964). Electron microscopic studies have confirmed the presence of two gonadotroph cell types in the rat (Farquhar \& Rinehart, 1954a, 1954b) and bat (Herlant, 1964; Bhiwgade et al.; Singh \& Krishna, 1994).

FSH cells in the pars distalis of estrus female are large ovoid to polyhedral. Golgi apparatus is hypertrophied. Mitochondria are hypertrophied with collapsed cristae. Rough surfaced endoplasmic reticulum is well developed. Secretory granules are spherical, 200$400 \mathrm{~nm}$ in diameter and show variable electron density. These ultrastructural features suggest that FSH cells are secretory and metabolically active during estrus. During pregnancy, FSH cells undergo hypertrophy. Nucleus is irregular in outline. Large number of mitochondria with collapsed cristae is present in the cytoplasm. The dilated cisternae of rough endoplasmic reticulum are sparsely dotted with ribosome and are distributed throughout the cytoplasm. Thus the cytoplasm appears vacuolated. A few electron dense granules are seen more towards the apical cytoplasm. The hypertrophy of FSH cells during late pregnancy is associated with filigreed cytoplasmic pattern giving a bizarre appearance, because of further dilation of cisternae of endoplasmic reticulum. Thus, ultrastructural features suggest that though the FSH cells appear degranulated during pregnancy but they are synthetically active and elaborate large amount of hormone. 
Ultrastructural characteristics of FSH cells of $T$. longimanus are similar to that reported in other bat species (Herlant, 1964; Azzali; Singh \& Krishna, 1994; Bhiwgade et al.; Seraphim). Muniz et al. studied ultrastructural characteristics of gonadotrophs of pregnant bat, M. myotis. The granules of the gonadotrophic cells are columnar or cuboidal and are medium electron density. The gonadotrophs of pregnant bat under experimental conditions show degranulation which display greatly increased development of the rough endoplasmic reticulum and Golgi apparatus, a large number of lysosomes and a large amount of degraded material. Azzali observed cytological changes in the LH cells of V. savi and V. piccolo with electron microscopy and suggest that delayed ovulation may be the result from insufficient quantities of LH and that the Graafian follicle is maintained by tonic secretion of FSH.

T. longimanus at Nagpur is a continuous breeder and pregnancies follow in quick succession. There is an alternation of two sides of genitalia. When one ovary shows corpus luteum and development of embryo in uterine horn during pregnancy, the contralateral ovary is not quiescent but shows folliculogensis, and at late pregnancy, ovary shows fully formed Graafian follicle. In the present study, ultrastructural features of FSH cells indicate that they are synthetically very active during estrus and pregnancy when ovary shows folliculogenesis and a Graafian follicle. Our observations suggest that the hypertrophied FSH cells at late pregnancy are necessary for maintaining Graafian follicle in the contralateral ovary, which is going to ovulate. The present observations are supported by the hormonal studies carried out by Singh \& Krishna (2000) on $T$. longimanus at Varanasi, where it exhibits diatocous breeding habits.

LH cells in the pars distalis of bat during early pregnancy show inconspicuous Golgi apparatus. Mitochondria are round with lamellar cristae. The cisternae of rough surfaced endoplasmic reticulum are dilated and are distributed throughout the cytoplasm. Large numbers of secretory granules $(250-350 \mathrm{~nm})$ of varying electron density are observed throughout the cytoplasm. However, during mid-pregnancy, Golgi zone is well developed. The cytoplasm is vacuolated because of dilation of cisternae of the rough endoplasmic reticulum. Secretory granules are very few and are distributed throughout the cytoplasm.

During late pregnancy, hypertrophied LH cells show the profiles of rough surfaced endoplasmic reticulum occupying a large part of the cytoplasm, displacing other cell constituents. Cytoplasm is extremely vacuolated due to dilation of cisternae of rough endoplasmic reticulum.
The hypertrophy of LH cells is associated with the filigreed cytoplasmic pattern giving a highly bizarre appearance to the cell as seen in the FSH cells during late pregnancy. The secretory granules are small and less in number and are distributed towards the periphery of the cell. These ultrastructural features indicate that though LH cells appeared degranulated during pregnancy but they are active and elaborate large quantities of hormone.

In $R$. leschenaulti, (Bhiwgade et al.) LH cells are angular in shape and have secretory granules $100-150 \mathrm{~nm}$ diameter. These secretory granules are of equal density and are irregularly distributed throughout the cytoplasm. Mitochondria are elongated and have light matrix. Golgi apparatus is prominent. In S. heathi, (Singh \& Krishna, 1994) LH cells have secretory granules $175-350 \mathrm{~nm}$ diameter in the pars distalis. These granules are irregularly distributed throughout the cytoplasm. The mitochondria are elongated or round shaped and Golgi complex is conspicuous. H. lankadiva (Seraphim) exhibits the phenomenon of embryonic diapause during pregnancy. The LH cells during embryonic diapause show well developed Golgi complex and rough surfaced endoplasmic reticulum. Mitochondria are numerous and have lamellar cristae and are present near the rough endoplasmic reticulum and Golgi complex. The secretory granules are few in number. The LH cells during embryonic diapause are not inactive but synthetically active, although activity is slowed down. The LH gonadotrophin volume in M. lucifugus lucifugus decreases after ovulation and remain low during pregnancy and lactation (Anthony \& Gustafson, 1984) and $M$. californicus (Richardson).

The ultrastructural characteristics exhibited by LH cells of different species of bats are similar to the ultrastructural features exhibited by LH cells of $T$. longimanus, supporting the present observations. Hypertrophy and hyperplasia of LH cells during late pregnancy and lactation is reported in a number of bats, T. melanopogon (Badwaik, 1988); M. lucifugus lucifugus (Anthony \& Gustafson); H. lankadiva (Seraphim) and H. speoris (Patil, 1974). The ultrastructural features of LH cells indicate that these cells are synthetically very active during pregnancy and there is a hypertrophy of cells at late pregnancy, supporting observations on LH cells of different species of bats during pregnancy.

Luteotrophic role of LH cells is reported in M. myotis (Herlant, 1956); M. schreibersii (Peyre \& Herlant, 1963a, b); T. melanopogon (Badwaik, 1988) and H. lankadiva (Seraphim). In the present study, ultrastructural features of LH cells indicate that these cells are synthetically very active during pregnancy and are hypertrophied at the end of 
pregnancy. Similarly the luteal cells of T. longimanus are steroidogenically very active (Nerkar \& Gadegone). Thus, LH cells may be stimulating luteal cells during pregnancy to secrete progesterone which is responsible for maintenance of pregnancy as reported in T. longimanus (Singh \& Krishna, 2002).

In the present study, the cell types, FSH, LH and LTH in the pars distalis of $T$. longimanus during pregnancy are active, elaborating hormones which are needed for the development of embryo in one uterine horn and folliculogenesis in contralateral horn as this bat is continuous breeder and pregnancies follow in quick succession.

\section{ACKNOWLEDGEMENTS}

The electron microscopy facilities provided by Dr. Arun Chitale, Department of Histopathology, Jaslok Hospital and Research Centre, Mumbai, are gratefully acknowledged. Our thanks are due to Mr. Dilip Kanaskar and Shivaji Bhosale for their excellent technical assistance.

NERKAR, A. A. \& GADEGONE, M. M. Caracterización ultraestructural de la pars distalis del murciélag cola de vaina hembra Indio, Taphozous longimanus (Hardwicke). Int. J. Morphol., 28(3):787-801, 2010.

RESUMEN: Las observaciones ultraestructurales actuales demuestran la presencia de seis tipos de células en la pars distalis de murciélagos Taphozous longimanus preñadas y no preñadas. En la pars distalis del T. longimanus, las células STH son redondas u ovaladas con un núcleo excéntrico, numerosos gránulos de secreción y un Golgi bien desarrollado que indican una célula en actividad de síntesis vigorosa, mientras que las llenas de gránulos de secreción con un complejo de Golgi reducido sugieren un estado celular de reserva o almacenamiento. Las células LTH se caracterizan por grandes gránulos de secreción, el retículo endoplásmico dilatado y numerosas mitocondrias en el citoplasma, indicando que estas células están hipertrofiadas y con una actividad sintética muy activa durante el embarazo. Células de ACTH se encuentran de forma individual o en grupos, son alargadas o angulares, con largos procesos citoplásmicos. El tamaño y la disposición periférica de los gránulos de secreción de ACTH son característicos de la célula. Células de TSH se distribuyen principalmente hacia la periferia de la pars distalis del T. longimanus. Ellos son alargadas, poligonales o de forma triangular. Los gránulos de secreción son pequeños, electrodensos, de 150-200 nm de diámetro. El retículo endoplasmático rugoso está muy bien desarrollado. En células FSH, los gránulos de secreción son pequeños (200 a 400 nm), menores en número y se distribuyen hacia la periferia de la célula. Células FSH muestran mitocondrias bien desarrolladas, Golgi y retículo endoplasmático rugoso que indica el estado activo de la FSH durante el estro y la preñez. La hipertrofia de las células de FSH y LH durante la preñez se asocia con un patrón citoplasmático filigrana dando una extraña apariencia. Al final de la preñez, las células de FSH y LH son muy activas y sintetizan grandes cantidades de hormonas, como producto del desarrollo de las organelos celulares.

PALABRAS CLAVE: Murciélago; Pars distalis; Ultrastructura; Preñez.

\section{REFERENCES}

Anthony, E. L. P. \& Gustafson, A. W. Seasonal variations in pituitary LH-gonadotropes of the hibernating bat Myotis lucifugus lucifugus: An immunohistochemical study. Am. J. Anat., 170:101-15, 1984.

Anthony, E. L. P. Endocrinology of reproduction in bats: central Control. In: Crichton, E. G. \& Krutzsch, P. H. (editors). Reproductive Biology of Bats. London, Academic Press, 2000. pp. 1-26.

Austin, C. R. \& Short, R. V. Hormones in reproduction. Reproduction in mammals. London, Cambridge University Press, 1972. p.148.

Azzali, G. Citologie adenoipofisaria dei Chirotteri con particolare riguardo alle cellule FSH, LH, ACTH e LTH. Ateneo Parmense Sezione I, Acta Biomed., 42:169-229, 1971.
Badwaik, N. K. Cytology and seasonal changes of the pituitary of the emballonurid bat. Taphozous melanopogon (Temnick) Proc. Indian Acad. Sci. (Anim Sci), 97:479-89, 1988.

Badwaik, N. K. Cytology of the Adenohypophysis of the Indian fruit bat Cynopterus sphinx gangeticus (Andreson). Trends in the Life Sciences (India), 6:67-77, 1991.

Bhiwgade, D. A.; Akolkar, V. V.; Menon, S. N.; Manekar, A. P. \& Senad, D. G. Ultrastructural and functional characteristics of anterior pituitary cells in the Indian fruit bat, Rousettus leschenaulti (Desmarest). Acta Anat., 135:129-41, 1989.

Bleier, W. J. Early embryology and implantation in the California leaf-nosed bat, Macrotus californicus. Anat. Rec., 182:237-54, 1975. 
Cameron, E. \& Foster, C. L. Ultrastructural changes in the adenohypophysis of metyrapone treated rabbits. $J$. Endocr., 52:343-7, 1972.

DeVries A. C. Interaction among social environment, the hypothalamic-pituitary- adrenal axis and behaviour. Horm. Behav., 41:405-13, 2002.

Farquhar, M. G. \&. F. Rinehart, J. F. Electron microscopic studies of the anterior pituitary gland of castrate rats. Endocrinology, 54:516-41, 1954a.

Farquhar, M. G. \& Rinehart, J. F. Cytologic alterations in the anterior pituitary gland following thyroidectomy: an electron microscope study. Endocrinology, 65:857-76, 1954b.

Gopalalakrishna A. Observations on the breeding habits and ovarian cycle in the Indian sheath- tailed bat, Taphozous longimanus (Hardwicke). Proc. Nat. Inst. Sci., India 21:29-41, 1955.

Harris, G. W \& Donovan, B. T. The Pituitary gland. London, Butterworths, 1966. pp.586, 670.

Herlant, M. Correlations hypophysogenitales chez le femelle de la chauve-souris, Myotis myotis (Borkhausen). Archs. Biol., 67:89-180, 1956.

Herlant, M. Electron microscope studies on the adenohypophysis of Myotis myotis during gestation. Gen. Comp. Endocr., 2:631, 1962.

Herlant, M. Apport de la microscopie electronique a l'etude du lobe anterieur de l'hypophyse. In: Cytologie de l'Adenohypophyse. Benoit, J. \& Dalage, C. (Eds.). Paris, Editions du Centre National dela Recherche Scientifique, 1963. pp.73-90.

Herlant, M. The cells of the adenohypophysis and their functional significance. Int. Rev. Cytol., 17:299-382, 1964.

Herlant, M. Cycle sexuel chez les chiropteres des regions temperees. In: Cycles Genitaux Saisonniers de Mammiferes, Canivene, R. (ed). Paris, Masson et Cle, 1968. pp.111-31.

Ishibashi, T. \& Shiino, M. Subcellular localization of prolactin in the anterior pituitary cells of the female Japanese house bat, Pipistrellus abramus. Endocrinology, 124:1056-63, 1989.
Kawamoto, K. Endocrine control of the reproductive activity in hibernating bats. Zool. Sci., 20:1057-69, 2003.

Krishna, A. \& Dominic, C. J. Reproduction in the Indian sheath tailed bat. Acta Theriol., 27:97-106, 1982.

Mikami, S. Light and electron microscopic investigation of six types of glandular cells of the bovine adenohypophysis. Cell Tissue Res., 105:457-82, 1970.

Mikami, S.; Chiba, S.; Hojo, H.; Taniguchi, K.; Kubokawa, K. \& Ishii, S. Immunocytochemical studies on the pituitary pars distails of the Japanese long-fingered bat, Miniopterus schreibersii fuliginosus. Cell Tissue Res 251:291-9, 1988.

Muniz, E.; Jiménez, L.; Gragera, R.; Fernandéz, A. \& Rua C. Ultrastructural changes in the gonadotrophic and prolactin cells of Myotis myotis under experimental conditions. Funct. Dev. Morphol., 1:15-8, 1991.

Murphy, B. D. \& James, D. A. Cells of the adenohypophysis of the mink (Mustela vision) identified by immunohistochemical and functional criteria. Acta Anat., 94:184-203, 1976.

Nakane, P. K. Classification of anterior pituitary cell types with immunoenzyme histochemistry. J. Histochem. Cytochem., 18:9-20, 1970.

Nerkar, A. A. \& Gadegone, M. M. Ultrastructural organization of the corpus luteum of the Indian emballonurid bat, Taphozous longimanus (Hardwicke). J. Endocrinol. Reprod., 11:76-81, 2007.

Nerkar, A. A. \& Gadegone, M. M. Fine structure of adrenal cortex in the Indian sheath-tailed bat, Taphozous longimanus (Hardwicke) during the reproductive cycle. Acta Anat., 2009 (in press).

Nerkar, A. A. \& Gadegone M. M. Ultrastructure of the thyroid gland in Indian sheath-tailed bat, Taphozous longimanus (Hardwicke) during the reproductive cycle. Zool. Sci., 2009 (in press).

Nakayama, I.; Nickerson, P. A. \& Skelton, F. S. An ultrastructural study of the adrenocorticotropic hormonesecreting cell in the rat adenohypophysis during adrenal cortical regeneration. Lab. Invest., 21:169-78, 1969.

Nunez, E. A. \& Gershon, M. D. Phasic secretion by follicular cells of the bat adenohypophysis during the prearousal period of their annual life cycle. Am. J. Anat., 165:111-20, 1980. 
O'Brien, G. M. Comparative morphology of the pituitary gland in Australian flying foxes (Megachiroptera: genus Pteropus). Anat. Rec., 244:70-7, 1996.

O’Brien, G. M.; McFarlane, J. R. \& Kearney, P. J. Pituitary content of luteinizing hormone reveals species differences in the reproductive synchrony between males and females in Australian flaying- foxes (genus Pteropus). Reprod. Fertil. Dev., 15:255-61, 2003.

Patil, D. R. Comparison of pituitary gland cytology in three species of leaf-nosed bat (Hipposideridae). J. Anat., 118:33-51, 1974.

Peyre, A. \& Herlant, M. Correlations hypo-physo-génitales chez la femelle du Minioptere (Miniopterus schreibersii B). J. Comp. Endocrinol., 3:726-7, 1963a.

Peyre, A. \& Herlant, M. Ovo-implantation différeé et corrélations hypophyso-génitales chez la femelle du Minioptère (Miniopterus schreibersii B). C. R. Hebd. Seances Acad. Sci. D, 257:524-6, 1963b.

Purves, H. D. Morphology of the hypophysis related to its function. In: Young, W. C. (ed). Sex and Internal Secretion. London, B. \& Cox, T. Ltd., 1961. pp. 162229.

Reeder, D. M. \& Kramer, K. M. Stress in free-ranging mammals: Integrating physiology, ecology and natural history. J. Mammal., 86:225-35, 2005.

Reeder, D. M.; Raff, H.; Kunz, T. H. \& Widmaier, E. P. Characterization of pituitary-adrenocortical activity in the Malayan flying fox (Pteropus vampyrus). J. Comp. Physiol. B., 176:513-9, 2006.

Rennels, E. G.; Bogclanove, E. M.; Arimura, A, Saito, M. \& Schally, A. V. Ultrastructural observations of rat pituitary gonadotrophs following injection of purified porcine LHRH. Endocrinology, 88:1318-26, 1971.

Richardson, B. A. The anterior pituitary and reproduction in bats. J. Reprod. Fertil., 56:379-89, 1979.

Seraphim, E. R. Endocrine interaction during different phases of the female reproductive cycle in Hipposideros lankadiva (Kelaart). Ph. D. thesis, RTM Nagpur Uni., Nagpur (India), 2004.

Singh, U. P. \& Krishna, A. Identification, localization and distribution of different cell types in adenohypophysis of female Vespertilionid bat, Scotophilus heathi: A combined histochemical, immunocytochemical and electron microscopic study. Proc. Inst. Nat. Sci. Acad., 60:115-27, 1994.

Singh, U. P. \& Krishna, A. Pituitary adrenocorticotrophic (ACTH) cells during reproductive cycle in a Vespertilionid bat, Scotophilus heathi. Acta Biol. Hung., 48:409-20, 1997.

Singh, U. P. \& Krishna, A. Seasonal changes in circulating testosterone and androstenedione concentration and their correlation with the anomalous reproductive pattern in the male Indian sheath-tailed bat, Taphozous longimanus. J. Exp. Zool., 287:54-61, 2000.

Singh, U. P. \& Krishna, A. Seasonal changes in circulating steroid concentration and their correlation with the ovarian activity in the female Indian sheath-tailed bat, Taphozous longimanus. J. Exp. Zool., 292:384-92, 2002.

Siperstein, E. R. \& Miller, K. J. Further cytophysiologic evidence for the dentity of the cells that produce adrenocorticotrophic hormone. Endocrinology, 86:451$86,1970$.

Viau V. Functional cross-talk between the hypothalamicpituitary-gonadal and -adrenal axes. J. Neuroendocrinol., 14:506-13, 2002.

Wismaier, E. P.; Harmer, T. L. Sulak, A. M. \& Kunz, T. H. Further characterization of the pituitary-adrenocortical responses to stress in Chiroptera. J. Exp. Zool., 269:4429, 1994.

Correspondence to:

Archana A. Nerkar

Cell Biology Section

Department of Zoology

Institute of Science

R. T. Road, Civil Lines

Nagpur 440001

INDIA

E mail: archana_nerkar1@yahoo.co.in

Received: 21-07-2009

Accepted: 24-03-2010 
